\title{
Üniversite Öğrencilerinde Yaşam Doyumu: Beş Faktör Kişilik Özellikleri, Bilinçli Farkındalık ve Yılmazlığın Rolü
}

DOI: 10.26466/opus.719138

\author{
Aytekin Nam* - Sinem Evin Akbay ** \\ * Uzman Psikolojik Danışman, Aktoprak İlkokulu \\ E-Posta: aytekinnam80@gmail.com \\ ORCID: 0000-0003-3128-3579 \\ ** Dr. Öğr. Üyesi, Mersin Üniversitesi \\ E-Posta: sinemakbay85@gmail.com \\ ORCID: $\underline{0000-0001-6189-1896}$
}

\begin{abstract}
Öz
Bu araştırmanın amacı, üniversite öğrencilerinin beş faktör kişilik kuramındaki kişilik özellikleri, bilinçli farkındalık ve yılmazlık düzeylerinin yaşam doyumlarım ne düzeyde yordadığın incelemektir. Araştırmanın çalışma grubunu, Gaziantep Üniversitesi'nin çeşitli fakülte ve yüksekokullarında 20182019 eğitim öğretim yılında eğitim almakta olan 351'i Kı, 203'ü Erkek toplam 554 lisans öğrencisi oluşturmaktadır. Araştırma modeli olarak genel tarama modellerinden ilişkisel tarama modeli kullanılmıştır. Araştırmada veri toplamak amacıyla araştırmacı tarafindan hazırlanan Kişisel bilgi formunun yanısıra Yaşam Doyumu Ölçeği, Beş Faktör Kişilik Ölçĕ̆i, Bilinçli Farkındalık Ölçeği ve Yılmazlık Ölçeği olmak üzere toplam 5 ölçek kullanılmıştır. Araştırma sonucunda elde edilen veriler SPSS paket program kullanılarak analiz edilmiştir. Yaşam Doyumu ile Beş Faktörlü Kişilik Özelliği, Bilinçli Farkındalık ve Yılmazlık düzeyleri arasındaki ilişkiyi incelemek için Pearson momentler çarpımı korelasyon katsayısı; beş faktör kişilik özelliği, Bilinçli farkındalık ve yılmazlık düzeylerinin öğrencilerin yaşam doyumların yordamadaki rolünü incelemek için çoklu regresyon analizi kullanılmıştır. Bu değişkenlerin yordama güçlerini belirleyebilmek için ise aşamalı(adımsal) regresyon analizi kullanılmıştır. Yapılan analizler sonucunda yılmazlık, bilinçli farkındalık ve nevrotiklik (duygusal dengesizlik) kişilik özelliği değişkenlerinin yaşam doyumunu anlamlı bir şekilde yordadığı sonucuna ulaşılmışıtır. Elde edilen bu sonuçlar tartışılarak gelecekte yapılacak çalışmalar için bazı öneriler sunulmuştur.
\end{abstract}

Anahtar Kelimeler: yaşam doyumu, beş faktör kişilik kuramı, bilinçli farkındalık, yılmazlık.

\footnotetext{
${ }^{1}$ Bu çalışma, Aytekin NAM tarafından Mersin Üniversitesi Eğitim Bilimleri Enstitü'nde Dr. Öğretim Üyesi Sinem Evin Akbay danışmanlığında yapılan yüksek lisans çalışmasının bir bölümüdür.
} 


\title{
Life Statisfaction Of University Students: The Five Factor Personality Traits, Mindfulness And The Role Of Resilience
}

\begin{abstract}
Aim of this research is to examine the extend to which characteristics of personality in five factor personality theory of university students, mindfulness and resilience level predicted their life satisfaction. The sample of research consists of 554 of which were 351 girls and 203 boys undergaduate students who were studying in University of Gaziantep in 2018-2019 Academic Year in total. Among the general survey models, the relational scanning model is employed as research model. Besides the Personal Information Form which is prepared by the researcher, in total 5 scales are utilized including The Satisfaction with Life Scale, Five Factor Personality Scale, Mindfulness Scale and Resilience Scale to collect data in the research. The gathered data in the result of the reseach has been analyzed by using SPSS package programme. In order to analyze the relation between Life satisfacion and Five Factor Personality Traits, and Mindfulness and Resilience level Pearson Product Moment Correlation Coefficient has been employed; in order to examine the role of prediction the Minfulness and Resilience Level on students' life satisfaction level Multiple Regression Analysis has been employed. Stepwise Regression has been used to determine the strength of prediction of these variables. In the results of the research, It has been concluded that resiliency, mindful attention awareness and neuroticism (mood disorders) personal traits variables predicts life satisfaction meaningfully. These gathered results from the research made suggestions by discussing in future studies.
\end{abstract}

Keywords: life satisfaction, five factor personality theory, mindfulness, resilience, 


\section{Giriş}

Uzun yıllardan beri tartışılan önemli konulardan bir tanesi de, iyi bir yaşamın nasıl olması gerektiğidir. Bu süreçte iyi bir yaşamın faziletli olmakla alakalı olduğu, bireyin yaşamındaki görev ve sorumluluklarını doğru bir biçimde yerine getirmesi gerektiği ya da neşeyle dolu olması gerektiği gibi çeşitli düşünceler ortaya atılmıştır (Diener ve Suh, 2000). İnsanlar için en önemli yaşam amaçlarından bir tanesi de mutu bir hayat sürdürebilmektir. Mutlu bir hayat nasıl sürdürülür, insanlar nasıl mutlu olabilir, mutluluk hangi faktörlerden etkilenir, mutluluk ne anlama gelir soruları hiçbir zaman güncelliğini yitirmemiştir (Çivitçi,2012).

Yaşam Doyumu kavramındaki "doyum” kelimesi bireylerin beklentilerinin, isteklerinin, gereksinimlerinin karşılanması olarak açıklanırken "Yaşam Doyumu" terimi bireyin beklentileriyle elinde var olanları kıyaslayarak genel bir değerlendirme yaptıktan sonra ulaştığı sonuçtur (Şahin,2008). Bireylerin mevcut yaşantısı idealindeki hayata ne kadar yakınsa yaşamından aldığı doyum da o denli yüksek olacaktır. Bu durumu formülleştirecek olursak yaşam doyumu=hayaller-hayatlar diyebiliriz. Burada fark arttıkça yaşam doyumu düşer, fark azaldıkça yaşam doyumu artar. Farkın sıfıra yakın olması yaşam doyumunun yüksek olduğuna işaret etmektedir. Özetle yaşam doyumu kişinin kendi hayatına ilişkin yaptığı öznel değerlendirmesi sonucunda ulaştı̆̆1 sonuçtur.

Karabulut ve Özer'e göre (2003) günlük yaşamlarında yaptıkları etkinliklerden zevk alan, kendilerini önemli ve değerli hisseden ve yaşama genelde pozitif bir bakış açısıyla bakan bireyler yaşam doyumu yüksek kişilerdir. Bireylerin hayatlarında karşılarına çıkan olumsuzluklar, engeller ya da çatışma durumlarında ise yaşam doyumlarında düşüş gözlenebilmektedir (Demirel ve Canat, 2004). Yılmaz bireylerin ise hayatlarında karşılarına çıkan bu olumsuz durum ve engellerde pes etmeyerek daha mücadeleci bir tavır sergilemeleri, bu durumların üstesinden gelebildiklerinde ise yaşam doyumlarının yüksek olabileceği düşünülmektedir. Bireyin yaşamından duyduğu doyum hayatın her döneminde olduğu gibi üniversite çağında, başka bir deyişle genç yetişkinlik döneminde de oldukça önemlidir. Üniversitede eğitim almak isteyen bireylerin çoğu yaşadıkları yeri, memleketlerini terk ederek başka bir şehre gitmektedir. Bunun bir sonucu olarak birey yeni bir şehirle, kültürle ve 
yaşam tarzıyla karşı karşıya kalmaktadır ve buna uyum sağlaması gerekmektedir. Bu durum birçok kişinin hayatında önemli değişikliklere ve beraberinde sorunlara yol açmaktadır (Özgür, Gümüş ve Durdu, 2010). Bütün bu zorlayıc durumlar karşısında bireyin bu durumun üstesinden gelmesi ve daha iyi bir gelişim göstermesine yarayan özellikler araştırılmak istenmiştir. $\mathrm{Bu}$ doğrulta yılmazlık değişkeni araştırmaya dahil edilmiştir.

Bireyin kendi yaşamına dair yapmış olduğu değerlendirmelerle ulaştı̆̆1 sonuç yaşam doyumunun belirleyicisidir. Üniversite dönemindeki bireylerin yaşam doyumları hayatlarının her alanını etkilediği için oldukça önemlidir. Üniversite dönemindeki kişi yetişkinliğe ilk adımlarını bu yıllarda atmaktadır. Bu dönem üniversite öğrencilerinin iş hayatına hazırlandıkları ve kendi değer sistemlerini oluşturdukları bir dönem olarak kabul edilebilir (Diener, 2000). Üniversite dönemi artık bireylerin kişiliklerinin oturduğu ve genç yetişkinliğe adım attı̆̆ bir dönemdir. Bu açıdan düşünüldüğünde üniversite dönemindeki gençlerin kişilik özelliklerinin yaşamlarının bu döneminde doyumları üzerinde ne derece etkili olduğu merak edilen bir sorudur.

Kişilik bireylerin doğuştan getirdiği ve onu diğer insanlardan ayıran kendine has mizacı ve farklı durumlar karşısında ortaya çıkan özelliklerinin toplamıdır (İbrahimoğlu, Ünaldı, Samancıŏlu ve Bağlıbel, 2013). Beş Faktör Kişilik Modeli İlk olarak 1985 yılında Paul Costa ve Robert Mcrae tarafından geliştirilmiştir (Merdan, 2013) daha sonraları çeşitli araştırmacılar tarafından farklı uluslardan farklı kişilik özellikleriyle yapılan çalışmalarla devam ettirilmiştir. Bu araştırmaların sonucunda kişiliğin beş boyutunun olduğuna dair bulgular elde edilmiştir. Yapılan araştırmaların hemen hepsinde ortaya çıkan bu beş faktör dolayısıyla bu kurama "beş faktör kişilik kuramı" ya da başka bir ifadeyle "büyük beşli" adı verilmiştir. Kısaca bu faktörler; dışadönüklük, deneyime açılık, öz disiplin(Sorumluluk), uyumluluk ve nevrotiklik olarak tanımlanmaktadır (Burger, 2006). Dışadönük kişilik özelliği baskın olan bireyler yaşamlarında aktiviteyi seven, sosyal, enerjik, konuşkan ve kararlı kişilerdir. Bu bireyler çabuk sinirlenebilir duygularını kontrol etmede ise zorlanabilirler. Yaşamlarında kaygı düzeyleri diğer insanlara göre daha azdır ve hayatlarındaki değişimlerden hoşlanırlar (Obuz, 2019). Beş Faktör Kişilik Kuramının uyumluluk boyutu saygılı olma, içtenlik, sempatiklik ve anlayışlı olma gibi özellikleri içerir (Morsünbül, 2014). Uyumlu kişiler sosyal ilişkilerinde kibar, affedici ve kendisi gibi düşünmeyen insanlara karşı saygılıdırlar (Bacanlı, İlhan ve Aslan, 2009). Sorumluluk boyutu ise hedefe odaklı olma, 
tertipli ve düzenli olma, liderlik edebilme, görev bilinci yüksek olma, kararlığ1 yüksek olma ve üretken olabilme gibi özellikleri içermektedir (Çivitçi ve Arıcıoğlu, 2012). Nevrotiklik (Duygusal dengesizlik) boyutu kaygılı, aşırı derecede evham yapan, yaşama karamsar bakan kişilerin baskın özelliklerini ifade eder (Ciccarelli, ve White, 2016). Bu bireyler çabuk heyecanlanan, genel olarak sinirli, çabuk endişelenen ve negatif duygusal eğilime sahip bireyler olarak nitelendirilmektedir (Uzunoğlu, 2006). İnanç ve Yerlikaya' ya göre (2017) Deneyime açıklık boyutunda bulunan özellikler şu şekilde sıralanabilmektedir: Yüksek hayal gücüne sahip, deneyime açık, bağımsız olmayı seven, yaratıcı, meraklı. Deneyime açıklık kişilik özelliği ağır basan bir diğer ifadeyle gelişime açı olan bireyler analitik zekaya sahip, geleneksel olmayan, ilgileri çeşitli, orijinal, hayal gücü yüksek, meraklı, yeni fikirlere açık, yaratıcı, değişikliği seven kişiler olarak nitelendirilmektedir (Somer, Korkmaz ve Tatar, 2002).

Hayatlarında aynı olayı yaşamış olan bireyler dahi bu durumlar karşısinda farklı tepkiler ortaya koymaktadır. Bunun nedenlerinden biri de kişilik özelliklerinin farklı olmasıdır. Bir toplumun gelenekleri, örf ve adetleri o toplumun yaşayışını ne denli etkiliyorsa, kişilik özellikleri de bireyin yaşantısı üzerinde oldukça büyük bir etkiye sahiptir (Erkuş ve Tabak, 2009). Farklı kişilik özelliklerine sahip bireylerin bu dönemde karşılarına çıkan durumlar karşısında verdiği tepkilerin yaşam doyumlarını ne düzeyde etkilediği merak edilmiş bu yüzden araştırmaya kişilik özellikleri değişkeni dahil edilmiştir.

Budistlerin kullandı̆̆ı eski bir uygulama da olan farkındalık kişinin kim olduğunu, dünyayı ve bu dünyadaki yerini nasıl gördüğünü sorgulamasıdır. Farkındalık (mindfulness) dikkatin şimdi ve burada odaklı olmasını, bireyin içsel deneyimlerini gözleyebilmesi ve bu deneyimlerin farkında olmasıdır. Birey bilinçli farkındalık halinde dikkatinin nerede olduğunun farkındadır ve zihnini meşgul eden şeyleri tam olarak fark eder. Kısaca bilinçli farkındalık kavramı bireyin tam manasıyla zihninde olanların farkında olmasıdır (Cengiz, Serdar ve Donuk, 2016).

Bilinçli farkındalık kavramı anda olmayı, geçmişin yaşanmışlıklarında ve geleceğin kaygılarından arınmış olmayı ifade eden bir kavramdır. Bireylerin farkındalık düzeyinin artması, acıyla etkili bir şekilde başa çıkabilmeyi, sosyal ilişkilerinden daha fazla doyum sağlayabilmeyi ve ruhsal sağlığın artma- 
sını sağlayan bir faktördür (Brown, Ryan ve Creswell, 2007). Bireylerin bilinçli olması iyi oluşu arttırmaktadır. Bireyin dikkatini ana vermesi ve ana odaklı olması mutlu olmayı ve iyilik halini doğrudan etkilemektedir (Brown ve Ryan, 2003). Özetle bilinçli farkındalık düzeyi yüksek bireyler şimdi ve burada odaklı bir yaşam sürmektedir ve yaşamı olduğu gibi kabul etmektedir. Yaşamdaki olumlu olumsuz tüm duyguların farkında olmak ve bunların üstesinden gelebilmek için çaba sarf etmek ise yaşamdan alınan doyum üzerinde etkili olmaktadır. Alanyazın incelendiğinde bilinçli farkındalığın psikolojik iyi oluşla ve yaşam doyumuyla olumlu bir ilişkisinin olduğu görülmektedir. Üniversite öğrencilerinin yaşam doyumlarının araştırıldığı bu çalışmada bilinçli farkındalık değişkeninin yaşam doyumu üzerindeki etkisini inceleyebilmek için bu değişken araştırmaya dahil edilmiştir.

Bireyin günümüzün stresli ve zorlayıcı yaşam koşullarının üstesinden gelebilmesi, yine kişinin zihinsel ve sosyal yetenekleri ile uyum becerilerine bağlıdır. Kişinin yaşamında karşılaştığı zorlayıcı durumlar, stresli olaylar ve tüm olumsuz şartlara rağmen sahip olduğu olumlu özellikler, bireyin çevrenin olumsuz etkilerini en aza indirmesinde ona yardımcı olur (Onat, 2010). Yılmazlık bireylerin zorlu ve stresli yaşam olayları karşısında sergilediği dirayetli duruş olarak da ifade edilebilir. Öğrencilik hayatı birçok stresli olayları ve zorlukları barındıran bir yaşam dönemidir. Bu zorluklar ve sıkıntılar karşısında yılmazlık özelliği daha yüksek olan bireylerin yaşam doyumlarının nasıl etkileneceği merak edilen bir durumdur. İlgili alan yazın incelendiğinde psikolojik dayanıklılık ve psikolojik sağlamlık kavramlarının yaşam doyumu ile ilişkisinin incelendiği çalışmalar göze çarpmaktadır. Bu çalışmada ise yılmazlık değişkeninin kullanılma sebebi üniversite öğrencilerinin yaşamlarında karşılaştığı güçlükler karşısında göstereceği irade, kararlılık, azim, vazgeçmeme ve pes etmeme davranışlarının yaşam doyumları üzerinde nasıl bir etkisinin olduğunu araştırmaktır. Bu davranışların yılmazlık değişkeniyle daha çok ilişkili olduğu düşünüldüğü için araştırmaya dahil edilmiştir.

Yapılan birçok çalışma incelendiğinde yaşam doyumu üzerinde yukarıda bahsedilen değişkenlerin etkilerinin ayrı ayrı araştırıldığı görülmektedir. $\mathrm{Bu}$ çalışmada ise kişilik özellikleri, bilinçli farkındalık ve yılmazlığın yaşam doyumunu birlikte ne düzeyde yordadığı araştırılmıştır. Böylece bu değişkenlerin birlikte yaşam doyumu üzerindeki etkisinin ne oranda olabileceği hakkında fikir edinilmeye çalışılmıştır. Ayrı ayrı yaşam doyumu üzerinde belirli 
bir oranda etkisi olduğu bilinen bu değişkenlerin birlikte yordama gücü bu araştırmanın temel dayanak noktası olmuştur.

\section{Yöntem}

\section{Araştırma Modeli}

Üniversite öğrencilerinin kişilik özelliklerinin, bilinçli farkındalık düzeylerinin ve yılmazlık düzeylerinin yaşam doyumlarını ne düzeyde yordadığını inceleyen bu çalışma betimsel bir araştırmadır. Araştırma modeli olarak genel tarama modellerinden ilişkisel tarama modeli kullanılmıştır.

\section{Çalışma Grubu}

Bu araştırmanın çalışma grubu 2018-2019 eğitim-öğretim yılı bahar döneminde Gaziantep Üniversitesinde öğrenim görmekte olan lisans ve ön lisans öğrencileri oluşturmaktadır. Çalışma grubunu 351 kadın (\%63) 203 erkek (\%37) toplam 554 kişi oluşturmaktadır. Katılımcıların yaş aralığı 17-46 arasında değişmektedir. Yaş ortalaması 22,85 standart sapması ise 3,60 olarak hesaplanmıştır. Araştırmaya katılan öğrencilerin 80'i 1. Sınıf, 33'ü 2. Sınıf, 305 tanesi 3. Sınıf, 136 tanesi 4. Sınıfta eğitimlerine devam etmektedir. Çalışma gurubunun oluşturulmasında kolay ulaşılabilen örnekleme yöntemi kullanılmiştır.

\section{Veri Toplama Araçlarn}

Kişisel Bilgi Formu: Kişisel Bilgi Formu araştırmacı tarafından hazırlanmış olup çalışma grubuna ilişkin yaş, cinsiyet, bölüm, sınıf düzeyi, genel akademik ortalama, daha önceden ciddi bir sağlık problemi yaşayıp yaşamadığ gibi konularda bilgi toplamak amacıyla hazırlanmıştır.

Yaşam Doyumu Ölçeği: Yaşam doyumu ölçeği (The Satisfaction With Life Scale) Diener, Emmons, Larsen ve Griffin tarafından 1985 yılında geliştirilmiştir. Yaşam Doyumunu ölçmek amacıyla geliştirilen bu ölçek 5 maddeden oluşan, tek boyutlu, geçerli ve güvenilir bir ölçme aracıdır. Ölçekten alınabilecek en düşük puan 5, en yüksek puan ise $25^{\prime}$ dir. Ölçekten alınan puanın yüksek olması bireylerin yaşamdan aldıkları doyumun artışına işaret ederken, ölçekten alınan düşük puan bireyin yaşamdan aldığı doyumun düşük 
olduğunu göstermektedir. Diener ve arkadaşlarının geliştirdiği orijinal ölçeğin iç tutarlılık güvenirlik katsayısı (Cronbach Alpha) 0.87, ölçüt geçerliği ise 0,82 olarak bulunmuştur. Ölçeğin Türkçe uyarlaması Baysal ve Dağlı (2016) tarafından yapılmıştır. Bu çalışmada ise, Yaşam Doyumu Ölçeği'nden elde edilen Cronbach Alpha değeri 0,84 olarak hesaplanmıştır.

Beş Faktör Kişilik Envanteri: Beş Faktör Kişilik Envanteri John, Donahue ve Kentle (1991) tarafından geliştirilmiştir. İlk olarak Büyük Beşli Ölçeği (The Big Five Inventory) adıyla geliştirilen bu ölçek 5'li likert tipinde 44 maddeden oluşmaktadır. Ölçek dışa dönüklük (8 madde), nevrotiklik/duygusal dengesizlik (8 madde), uyumluluk/yumuşak başlılık (9 madde), sorumluluk/öz disiplin ( 9 madde) ve deneyime açıklık (10 madde) olmak üzere beş faktörden oluşmaktadır (Durmuş, Ulusoy, 2011).

Bu çalışmada ise Sümer ve Sümer (2005) tarafından Türkçeye Uyarlaması yapılan Beş Faktör Kişilik Ölçeği kullanılmıştır. Her bir alt ölçekten alınan yüksek puanlar söz konusu boyuttaki kişilik özelliğinin yüksek olduğu anlamına gelmektedir. Sümer (2005) yaptığı çalışmasında ölçeğin boyutlarının Cronbach Alpha değerlerini 64 ile 77 arasında bulmuştur.

Bu çalışmada ise ölçeğin tüm alt boyutlarına ilişkin elde edilen Cronbach Alpha değerleri şu şekildedir: Dişadönüklük alt ölçeğinin Cronbach Alpha değeri 0,70 ; Uyumluluk alt ölçeğinin Cronbach Alpha değeri 0,63 ; Sorumluluk alt ölçeğinin Cronbach Alpha değeri 0,70 ; Nevrotiklik alt ölçeğinin Cronbach Alpha değeri 0,73; Açıklık alt ölçeğinin Cronbach Alpha değeri 0,73 olarak hesaplanmıştır. Beş faktör kişilik envanterinin alt boyutları için hesaplanan Cronbach Alpha değerlerine bakıldığında tüm ölçeklerin 0,60 ile 0,90 arasinda yer aldığı görülmektedir.

Bilinçli Farkındalık Ölçeği: Bilinçli Farkındalık Ölçeği Brown ve Ryan (2003) tarafından günlük yaşamdaki anlık deneyimlerin farkında olma ve bunlara karşı dikkatini verebilme yönündeki eğilimi ölçmek amacıyla geliştirilmiştir. Bilinçli Farkındalık Ölçeği 15 maddeden oluşan 6'lı likert tipli ve tek faktörlü bir ölçektir. 1=Hemen hemen her zaman, $6=$ hemen hemen hiçbir zaman cümlesini ifade eder. Ölçekten alınabilecek minimum puan 15 iken maksimum alınabilecek puan ise 90'dır. Puanların artması bilinçli farkındalık düzeyinin de artığını göstermektedir (Sarıçalı, Satıcı, 2017). Bilinçli Farkındalık Öl- 
çeği'nin Cronbach Alpha güvenirlik katsayısı 0,76 ve test-tekrar-test güvenirlik katsayısı 0,86 olarak bulunmuştur. Bu çalışmada ise ölçeğin Cronbach Alpha değeri 0,81 olarak hesaplanmıştır.

Yılmazlık Ölçeği: Yılmazlık Ölçeği Gürgân (2006) tarafından Lise ve Üniversite düzeyindeki kişilerin yılmazlık düzeylerini incelemek amacıyla geliştirilmiş bir ölçektir. Ölçek 5'li likert tipinde 50 maddeden oluşan 8 faktörlü bir ölçme aracıdır. Ölçekten alınabilecek en düşük puan 50 en yüksek puan ise 250 'dir. Yüksek puanlar yüksek düzeyde bir yılmazlığı göstermektedir. İç tutarlılık için hesaplanan Cronbach Alpha katsayısı ilk uygulamada 0,78 ikinci uygulamada 0,87 olarak bulunuştur (Gürgân,2006). Bu çalışmada ise ölçeğin Cronbach Alpha değeri 0,95 olarak hesaplanmıştır.

\section{Verilerin Toplanması ve Analizi}

Bu çalışmanın verileri 2018-2019 eğitim-öğretim yılında Gaziantep Üniversitesi'nde Eğitim Fakültesi, Hukuk Fakültesi, İlahiyat Fakültesi, Fen Edebiyat Fakültesi, İletişim Fakültesi, Tıp Fakültesi, Mühendislik Fakültesi, Güzel Sanatlar Fakültesi, İktisadi ve İdari Bilimler Fakültesi, Spor Bilimleri Fakültesi, Türk Musikisi Devlet Konservatuarı, Turizm ve Otelcilik Meslek Yüksek Okulunda eğitim almakta olan çeşitli sınıf düzeylerindeki lisans ve ön lisans öğrencilerine uygulanan veri toplama araçları yoluyla elde edilmiştir. Verileri toplayabilmek için Gaziantep Üniversitesi Rektörlüğü'nden gerekli Uygulama İzni (EK-1) alınmıştır. Sınıflarda uygulama yapabilmek için öğretim elemanlarından gerekli izinler alınarak ölçekler sınıflardaki öğrencilere uygulanmıştır. Uygulama öncesinde öğrencilere araştırmaya ilişkin bilgiler verilerek "Bilgilendirilmiş Onay Formu”" dağıtılmış ve katılmak isteyenlerin gönüllülük esasına göre imzalamaları sağlanmıştır. Uygulamaya katılan tüm öğrencilere gizliliğe yönelik gerekli bilgilendirmeler yapılmıştır.

Üniversite öğrencilerinin kişilik özelliklerinin, bilinçli farkındalık düzeylerinin ve yılmazlık düzeylerinin yaşam doyumlarını ne düzeyde yordadığ1nın amaçlandığı bu araştırmada kişisel bilgi formu, yaşam doyumu ölçeği, beş faktör kişilik envanteri, bilinçli farkındalık ölçeği ve yılmazlık ölçeğinden elde edilen veriler SPSS 22. paket programı kullanılarak analiz edilmiştir. Araştırmada ilk olarak çoklu regresyon analizi varsayımları sınanmıştır. Bu işlem için öncelikle tüm ölçme araçlarından elde edilen puanların normal da- 
ğılıp dağılmadığı test edilmiştir. Ardından yordayıcı ve yordanan değişkenler arasındaki ilişkinin doğrusallığı test edilmiştir. Bu analiz için SPSS deki saçılma diyagramı yöntemi kullanılmıştır. Araştırmada incelenen değişkenler arasındaki ilişkileri belirleyebilmek için Mahanolobis sonuçları da göz önüne alınarak Pearson Korelasyon Katsayıları hesaplanmıştır.

Ardından beş faktör kişilik özellikleri, bilinçli farkındalık ve yılmazlık değişkenlerinin yaşam doyumunun anlamlı birer yordayıcıları olup olmadığını görebilmek için çoklu regresyon analizi yapılmıştır. Yordayıcı değişkenlerin ayrı ayrı yordama güçlerini belirleyebilmek için ise Aşamalı(adımsal) Regresyon analizi kullanılmıştır. Çalışmada yapılan analizler için anlamlılık değeri .01 olarak kabul edilmiştir.

\section{Bulgular}

Örneklemi oluşturan 554 üniversite öğrencisi için yordanan değişken olan yaşam doyumu ile yordayıcı değişkenler olan (beş faktör kişilik özellikleri, bilinçli farkındalık ve yılmazlık) arasındaki Pearson korelasyon katsayıları Tablo 2'de verilmiştir.

Tablo 1. Yaşam Doyumu, Dışadönüklük, Uyumluluk, Sorumluluk, Nevrotiklik, Açıklık, Bilinçli Farkındalık Yılmazlık Arasındaki Korelasyonlar

\begin{tabular}{|c|c|c|c|c|c|c|c|c|}
\hline & 1 & 2 & 3 & 4 & 5 & 6 & 7 & 8 \\
\hline 1.Yaşam Doyumu & - & & & & & & & \\
\hline 2.Dişadönüklük & $28^{* *}$ & - & & & & & & \\
\hline 3.Uyumluluk & $14^{* *}$ & $33^{* *}$ & - & & & & & \\
\hline 4. Sorumluluk & $25^{* *}$ & $34^{* *}$ & $38^{* *}$ & - & & & & \\
\hline 5. Nevrotiklik &,$- 29^{* *}$ &,$- 33^{* *}$ &,$- 22^{* *}$ &,$- 28^{* *}$ & - & & & \\
\hline 6. Açıklık & $17^{* *}$ & $45^{*}$ & $36^{* *}$ & $38^{* *}$ &,$- 13^{* *}$ & - & & \\
\hline 7. Bilinçli Farkındalık & $34^{* *}$ & $20^{* *}$ & $27^{* *}$ & $31^{* *}$ &,$- 27^{* *}$ & $26^{* *}$ & - & \\
\hline 8. Yilmazlik & $43^{* *}$ &, $53^{* *}$ & $39^{* * *}$ & $48^{* *}$ &,$- 37^{* *}$ &, $52^{* *}$ & $45^{* *}$ & - \\
\hline Aritmetik Ortalama & 13,68 & 27,03 & 34,90 & 31,49 & 25,34 & 37,52 & 57,75 & 184,77 \\
\hline Ss & 4,32 & 5,41 & 5,18 & 5,77 & 6,06 & 5,99 & 12,03 & 32,40 \\
\hline
\end{tabular}

Tablo 1'e bakıldığında üniversite öğrencilerinin yaşam doyumu ile dışadönüklük kişilik özelliği $\quad(\mathrm{r}=.28, \mathrm{p}<.001)$ arasında pozitif yönlü anlamlı bir ilişki; Yaşam doyumu ile uyumluluk kişilik özelliği $(r=.14, p<.001)$ arasında pozitif yönlü anlamlı bir ilişki; Yaşam doyumu ile sorumluluk kişilik özelliği $(\mathrm{r}=.25, \mathrm{p}<.001)$ arasında pozitif yönlü anlamlı bir ilişki; Yaşam doyumu ile nevrotiklik kişilik özelliği $(r=-.29$, p<.001) arasında negatif yönlü anlamlı bir 
ilişki; Yaşam doyumu ile açıklık kişilik özelliği ( $\mathrm{r}=.17$, p<.001) arasında pozitif yönlü anlamlı bir ilişki; Yaşam doyumu ile bilinçli farkındalık ( $\mathrm{r}=.34$, $\mathrm{p}<.001$ ) arasında pozitif yönlü anlamlı bir ilişki; Yaşam doyumu ile yılmazlık $(\mathrm{r}=.43, \mathrm{p}<.001)$ arasında pozitif yönde anlamlı bir ilişki olduğu sonucuna varılmıştır. Bu bulgulara göre üniversite öğrencilerinin beş faktör kişilik özelliğindeki dışadönüklük, uyumluluk, sorumluluk ve açıklık kişilik özellikleri arttıkça yaşam doyumları da artmaktadır. Ancak beş faktör kişilik özeliklerinden nevrotiklik düzeyi arttıkça yaşam doyumları azalmaktadır. Üniversite öğrencilerinin bilinçli farkındalık düzeyleri arttıkça yaşam doyumları da artmaktadır. Aynı şekilde yılmazlığın artmasının da yaşam doyumunu arttıran faktörlerden birisi olduğu sonucuna ulaşılmıştır.

Tablo 2. Yaşam Doyumunun Yordayıcılam Olarak Beş Faktör Kişilik Özellikleri, Bilinçli Farkındalık ve Yılmazlı̆̆a İlişkin Çoklu Regresyon Analizi Sonuçları

\begin{tabular}{|c|c|c|c|c|c|}
\hline & B & $\mathrm{SH}_{\mathrm{B}}$ & $\beta$ & $t$ & $\mathrm{p}$ \\
\hline Sabit & 5,397 & 1,870 & - & 2,887 & ,004 \\
\hline Dişadönüklük & ,077 & ,037 & 0,96 & 2,050 & ,041 \\
\hline Uyumluluk &,- 059 & ,036 &,- 071 & $-1,653$ & ,099 \\
\hline Sorumluluk & ,035 & ,034 & ,046 & 1,029 & ,304 \\
\hline Nevrotiklik &,- 076 & ,030 &,- 107 & $-2,541$ & ,011 \\
\hline Açıklık &,- 063 & ,034 &,- 087 & $-1,854$ &, 064 \\
\hline Bilinçli Farkındalık &, 064 & ,015 & 178 & 4,160 &, 000 \\
\hline Yilmazlik & 0,42 & 0,07 & ,315 & 5,837 &, 000 \\
\hline
\end{tabular}

$\mathrm{R}^{2}=.244 ; \mathrm{F}_{7-552}=25,072, \mathrm{p}<.001$

Tablo 2'ye bakıldığında örneklemin tamamının beş faktör kişilik özelliklerinin(dışadönüklük, nevrotiklik,), bilinçli farkındalık ve yılmazlık değişkenlerinin üniversite öğrencilerinin yaşam doyumunu anlamlı bir şekilde yordadığı sonucuna ulaşılmıştır $\left(\mathrm{F}_{7-552}=25,072, \mathrm{p}<.001\right)$. Elde edilen bu sonuca göre tüm bağımsız değişkenler birlikte yaşam doyumunu \%24,4 oranında açıklamaktadırlar. Ancak beş faktör kişilik özelliklerinden uyumluluk, sorumluluk ve açılık kişilik özelliklerinin yaşam doyumunun anlamlı bir yordayıcısı olmadı̆̆ı görülmüştür. 
Tablo 3. Yaşam Doyumunun Yordayıcıları Olarak Yılmazlık, Bilinçli Farkındalık ve Nevrotikliğe İlişkin Aşamalı Regresyon Analizi Sonuçlan

\begin{tabular}{|c|c|c|c|c|c|c|c|c|c|c|}
\hline \multirow{2}{*}{$\frac{\text { Model }}{1}$} & Değişkenler & B & $\mathbf{S H}_{\mathrm{B}}$ & $\beta$ & $t$ & p & $\mathbf{R}$ & $\mathbf{R}^{2}$ & $\mathbf{F}$ & p \\
\hline & Sabit & 2,946 & ,958 & - & 3,074 & ,002 & \multirow{2}{*}{,436 } & \multirow{2}{*}{ 190 } & \multirow[b]{2}{*}{129,272} & \multirow{2}{*}{,000 } \\
\hline & Yllmazlık & ,058 & ,005 & ,436 & 11,370 & ,000 & & & & \\
\hline \multirow[t]{3}{*}{2} & Sabit & 1,205 & 1,027 & - & 1,174 & 241 & \multirow{3}{*}{,465 } & \multirow{3}{*}{,216 } & \multirow{3}{*}{75,956} & \multirow{3}{*}{ 000 } \\
\hline & Yllmazlık & 047 & 0,06 & 353 & 8,329 & 000 & & & & \\
\hline & Bilinçli Farkındalık & ,066 & ,015 & 182 & 4,305 & ,000 & & & & \\
\hline \multirow[t]{4}{*}{3} & Sabit & 4,880 & 1,548 & - & 3,152 & 002 & \multirow{4}{*}{ 480 } & \multirow{4}{*}{ 226 } & \multirow{4}{*}{54,770} & \multirow{4}{*}{,000 } \\
\hline & Yllmazlık & 042 & 006 & 312 & 7,102 & 000 & & & & \\
\hline & Bilinçli Farkındalık & ,059 & 015 & 165 & 3,895 & 000 & & & & \\
\hline & Nevrotiklik &,- 091 & ,029 & -128 & $-3,152$ & ,002 & & & & \\
\hline
\end{tabular}

Aşamalı regresyon analizi sonuçlarına bakıldığında standardize edilmiş regresyon katsayıları $(\beta)$ sırasıyla şu şekildedir: Yılmazlık $(\beta=, 312)$, Bilinçli farkındalık $(\beta=, 165)$ ve Nevrotiklik $(\beta=-, 128)$ değişkenleri üniversite öğrencilerinin yaşam doyumların istatistiksel açıdan anlamlı bir şekilde yordamaktadır. $\left(\mathrm{F}_{3-553}=54,770, \mathrm{p}<.001\right)$. Bu sonuca göre araştırmadaki bağımsız değişkenlerin yordama güçleri sırasıyla şu şekildedir: Yılmazlık değişkeni üniversite öğrencilerinin yaşam doyumu puanlarını yordayan en güçlü değişkendir ve tek başına toplam varyansın \%19'unu açılamaktadır.

Yılmazlık ve Bilinçli Farkındalık değişkenleri ise birlikte toplam varyansın \%21,6'sını açıklamaktadır. Yılmazlık, Bilinçli Farkındalık ve Nevrotiklik değişkenleri birlikte yaşam doyumu puanlarının \%22,6'sını yordamaktadır $(\mathrm{R}=$ $\left..480, \mathrm{R}^{2}=.226\right)$.

\section{Tartışma ve Sonuç}

\section{Yaşam Doyumunu Yordayan Değişkenler}

Çalışmadan elde edilen sonuçlara göre nevrotiklik kişilik özelliği, bilinçli farkındalık ve yılmazlık değişkenlerinin yaşam doyumunun anlamlı bir yordayıcısı olduğu sonucuna ulaşılmıştır.Bu bulgularla birlikte üniversite öğrencilerinin beş faktör kişilik özellikleri, bilinçli farkındalık ve yılmazlık değişkenlerinin birlikte yaşam doyumu puanlarını \%24,4 oranında açıkladığı sonucuna ulaşılmıştır.

Gürgan (2014) üniversite öğrencileri üzerine yaptığı çalışmada yılmazlık değişkeni ile iyilik hali arasında pozitif yönlü anlamlı bir ilişkinin olduğu sonucuna ulaşmıştır. Benzer şekilde Alibekiroğlu ve ark. (2018) üniversite öğrencileri üzerine yaptığı çalışmasında, Şahin (2014) öğretmenler üzerinde 
yaptığı çalışmasında; Uz Baş ve Yurdabakan (2017) ise ortaokul öğrencileri üzerine yaptığı çalışmasında, psikolojik sağlamlık ve yaşam doyumu arasında pozitif bir ilişkinin bulunduğunu ve psikolojik sağlamlığın yaşam doyumunu anlamlı bir şekilde yordadığını tespit emişlerdir. Özdaş (2017) yetişkinler üzerinde yaptığı araştırmada yaşam doyumu ve psikolojik dayanıklılık arasındaki ilişkiyi incelemiştir. Araştırma sonucunda yaşam doyumu ile psikolojik dayanıklılık arasında pozitif bir ilişkinin olduğunu ve psikolojik dayanıklılığın yaşam doyumunu anlamlı bir şekilde yordadığı tespit edilmiştir. Benzer şekilde Batan ve Ayten (2015) de yaptıkları çalışmada benzer sonuçlar elde etmiştir. Tümlü ve Recepoğlu (2013) Üniversitedeki akademik personel üzerinde yaptıkları çalışmalarında alan yazın ile benzer şekilde yaşam doyumu ve psikolojik dayanıklılık arasında pozitif yönlü anlamlı bir ilişkinin olduğunu ve psikolojik dayanıklılığın yaşam doyumunu anlamlı bir şekilde yordadığını tespit etmişlerdir. Alan yazında bu çalışmalar ile tutarlılık gösteren birçok çalışma yer almaktadır (Moran ve Hughes, 2012; Limonero ve ark. ,2012; Çelik, Sanberk ve Deveci, 2017; Orhan, 2018). Alanyazın incelendiğinde hem psikolojik sağlamlık hem psikolojik dayanıklılık kavraminın yılmazlık ile ortak yönleri olduğu görülmektedir. Bu üç kavramda da bireyin yaşamında ciddi engeller, zorlanmalar, stresli ve kaygıll yaşam olayları, travmalar kısacası bireyin yaşamını doğrudan etkileyen olaylar bulunmaktadır. Bireyin bu zorlayıcı yaşam durumlarıyla baş edebilme becerisi ise bu üç kavramla ilişkilendirilmiştir. Psikolojik dayanıklılık ve psikolojik sağlamlık ile yaşam doyumu arasındaki ilişkilerin araştırıldığ çalışmalarda bu değişkenlerin yaşam doyumunu arttırıc bir etkiye sahip olduğu sonucuna ulaşılmıştır.

İlgili alan yazın ile birlikte değerlendirildiğinde elde edilen bu sonuçların literatürle örtüştüğü görülmektedir. Bu araştırmada üniversite öğrencilerinin yaşam doyumlarını en iyi yordayan değişkenin yılmazlık olduğu sonucuna ulaşılmıştır. Yılmazlık azimli olmayı, vazgeçmemeyi, güçlü bir iradeye sahip olmayı, kararlı olmayı ve zorluklar karşısında pes etmemeyi içeren bir kavramdır. Üniversite öğrencilerinin yaşamlarında bu özelliklere sahip olması çevrelerindeki birçok olumsuz durumu en az zararla atlatmalarına ve daha güçlü bir şekilde gelişim göstermelerine yardım etmektedir. Yaşamlarında pes etmeyen bir diğer ifadeyle yılmayan kimselerin olumsuz yaşam olayla- 
rından daha da güçlü bir şekilde çıtığı düşünüldüğünde yaşam doyumunun daha yüksek olmasında yılmazlık özelliğinin önemli bir katkısının olduğu görülmüştür.

Özetle bu araştırmada üniversite döneminde zorlayıcı ve stres yaratan durumlarla karşılaşan bireylerin yılmazlık düzeylerinin yüksek olmasının yaşam doyumlarını arttıran bir faktör olduğu belirlenmiştir. Alanyazın incelendiğinde bu çalışmada ulaşılan yılmazlık değişkeninin yaşam doyumunun anlamlı bir yordayıcısı olduğu sonucu desteklenmektedir. Dolayısıyla üniversite öğrencilerinin yılmazlık özelliklerinin artması yaşamlarından daha fazla doyum almalarına yardımc olmaktadır.

Dönmez (2018) 12-55 yaş arasındaki bireyler için yaptığı çalışmasında, Deniz, Erus ve Büyükcebeci (2017) ise üniversite öğrencileri üzerine yaptıkları çalışmalarında bilinçli farkındalık ve yaşam doyumu arasında istatistiksel olarak anlamlı pozitif bir ilişkinin olduğunu ve bilinçli farkındalığın yaşam doyumunu anlamlı bir şekilde yordadığı sonucunu elde etimişlerdir.

Zümbül (2019) öğretmen adayları üzerine yaptığı çalışmasında bilinçli farkındalık ve psikolojik iyi oluş arasındaki ilişkiyi incelemiştir. Araştırma sonucunda bilinçli farkındalık ile psikolojik iyi oluş arasında pozitif yönlü anlamlı bir ilişki bulunmuştur. Bununla birlikte bilinçli farkındalığın psikolojik iyi oluşun anlamlı bir yordayıcı olduğu ve bu çalışmadaki de en güçlü yordayıc konumunda olduğu nitelendirilmiştir.

(Yıkılmaz ve Güdül, 2015; Tuncer, 2017; Şahin, 2019) üniversite öğrencileri üzerine yaptıkları çalışmalarında yaşam doyumu ve bilinçli farkındalık arasındaki ilişkinin pozitif yönlü ve anlamlı olduğunu bununla birlikte bilinçli farkındalık değişkeninin yaşam doyumu anlamlı bir şekilde yordadığı bulgusunu elde etmişlerdir.

Dolayısıyla bilinçli farkındalık düzeyi yüksek olan insanların yaşam doyumlarının yüksek olduğu görülmektedir. Bu durum bireylerin hayatlarına yönelik algısını da olumlu yönde etkilemektedir (Tümkaya ve ark., 2008). Alan yazında yabancı çalışmalar da incelendiğinde bilinçli farkındalık ve yaşam doyumu arasında poizitif yönlü bir ilişkinin olduğu sonucuna ulaşan çalişmalar olduğu görülmektedir (Brown ve Ryan, 2003; Brow ve Kasser, 2005; Bown ve ark., 2007; Howell ve ark., 2008; Schutte ve Malouff, 2011; Wang ve Kong, 2014; Griebel, 2015).

Bireylerin yaşanılan anda olması, duygu ve düşüncelerinin farkına varabilmesi ve bunları ifade edebilecek uygun yollar bulabilmesi yaşam kalitesini 
arttıran faktörlerden birisidir. Farkındalık düzeyi yüksek olan bireylerin yaşamdan daha fazla haz aldıkları, daha mutlu olduklarını söylemek mümkün görünmektedir. Şimdi ve burada odaklı yaşayan ve hayatı olduğu gibi kabul eden bireyler kendi iç dünyasında bir çelişki yaşamamaktadır. Var olan durumları kabul ederek bunun farkında olan bireyler yaşamlarından daha fazla doyum elde etmektedirler. Üniversite öğrencileri üzerine yapılan bu çalışmada bireylerin farkındalık düzeyinin artmasının yaşam doyumlarını da arttırdığı sonucu bu düşünceyi desteklemektedir.

Literatürdeki bu konuyla ilgili çalışılmış araştırmalar incelendiğinde bu araştırmada ulaşılan sonuçlarla tutarlılık gösterdiği görülmüştür. Üniversite öğrencilerinin bilinçli farkındalık düzeylerinin artması yaşam doyumunu da arttıran faktörlerden birisi olarak belirlenmiştir. Yıkılmaz ve Güdül'e göre (2015) Son zamanlarda bilinçli farkındalığın arttırılmasına yönelik yapılan müdahalelerin bireylerin yaşam doyumlarını da arttırması bunun bir göstergesidir.

Eryılmaz ve Öğülmüş (2010) yaptıkları çalışmada ergenler üzerine Doğan (2013) ise yetişkinler üzerine yaptığı çalışmasında beş faktör kişilik özellikleri ile öznel iyi oluş arasındaki ilişkiyi incelemiştir. Araştırma sonuçlarına göre nevrotiklik ile öznel iyi oluş arasında negatif, diğer kişilik özellikleri ile pozitif bir ilişkinin bulunduğu tespit edilmiştir. Bununla birlikte nevrotiklik kişilik özelliğinin öznel iyi oluşu anlamlı bir şekilde yordadığı bulgusu elde edilmiştir.

Reisoğlu (2014) ve Reisoğlu ve Yazıcı (2017) tarafından üniversite öğrencileri üzerine yapılan araştırmalarda kişiliğin nevrotiklik (duygusal dengesizlik) ve dışadönüklük boyutlarının öznel iyi oluşu anlamlı bir şekilde yordadığ1 sonucuna ulaşmışlardır. Öznel iyi oluşüzerinde nevrotikliğin negatif, d1şadönüklüğün ise pozitif etkisi olduğu belirlenmiştir. Bu çalışmaların sonuçları literatürdeki araştırma sonuçlarıyla tutarlık göstermektedir(Albuquerque ve ark., 2012; Furnham ve Pertrides,2003; Morrison, 1997; Penley ve Tomaka,2002;)

Nevrotik bireyler yaşamlarında duygusal anlamda çokça tutarsızlık yaşayan, kaygıll, depresif, olumsuz bir benlik algısına sahip kişilerdir. Bu durum olumsuz birçok duyguyu hayatlarında çokça yaşamalarına neden olmaktadır. Bireyin yaşamında duygusal anlamda fazlaca tutarsızlık yaşaması öznel iyi oluşunu da olumsuz yönde etkilemektedir. Kendini iyi hisseden bireyler yaşamlarından daha fazla doyum sağlamaktadır. Yukarıdaki araştırmalar da 
dikkate alındığında kişiliğin nevrotiklik alt boyutunun yaşam doyumunu olumsuz yönde etkilemesi kaçınılmazdır. Nitekim nevrotiklik ile yaşam doyumu arasındaki ilişkileri inceleyen çalışmalar da bu sonuçlarla paralellik göstermektedir.

Weber ve Huebner (2015) yaşam doyumu ile ilgili yaptığı çalışmasında yaşam doyumu ile nevrotiklik arasında negatif yönlü anlamlı bir ilişki bulurken, beş faktör kişilik özelliklerinin diğerleriyle(Dişaönüklük, uyumluluk, sorumluluk, deneyime açıklık) pozitif yönlü anlamlı bir ilişki olduğunu belirlemiştir. Bu sonuçlar bu araştırmanın bulgularıyla tutarlık göstermektedir. Bunun yanında bu araştırmada nevrotikliğin yaşam doyumunun anlamlı bir yordayıcısı olduğu sonucu da elde edilmiştir. Ercan (2019) ergenler üzerine yaptığı çalışmasında anne-baba tutumları, kişilik özellikleri ve yaşam doyumu arasındaki ilişkileri incelemiştir. Çalışma sonucunda beş faktör kişilik özelliklerinden nevrotiklik ile yaşam doyumu arasında negatif yönlü anlamlı bir ilişki olduğu sonucuna ulaşılırken dışadönüklük, uyumluluk ve sorumluluk ile pozitif yönlü anlamlı bir ilişki olduğu bulgusu elde edilmiştir. Alan yazın incelendiğinde bu sonuçların hem bu çalışmanın hem de bu konuda yapılmış önceki çalışmaların sonuçlarıyla örtüştüğü görülmektedir. Nevrotiklik kişilik özelliği baskın olan bireyler yaşamlarında hüzün, elem, öfke, pişmanlık, kaygı ve stres gibi duyguları yaşamaya daha eğilimlidirler. Heady ve Wearing'e göre (1989) bu duyguları daha sık yaşayan bireylerin olumsuz yaşam olaylarıyla daha fazla karşılaşması muhtemeldir. Bu duygu ve düşünceler, kişinin problemli davranışlar sergilemesine ve duygusal anlamda tutarsızlıkları daha sık yaşamasına neden olur. Bu durum bireyin yaşam doyumunun azalmasına sebep olmaktadır.

Üniversite öğrencileri üzerine yapılmış bu çalışmada yaşamlarında olumsuz duygulanma eğilimine sahip, evham yapan, kaygılı ve duygularında tutarsızlık yaşayan bireylerin yaşamlarından tat alamadığı, bir diğer ifadeyle yaşam doyumlarının düşük olduğu görülmüştür. Üniversite hayatı sosyal ilişkilerin sıkça olduğu, sınav dönemlerinin fazla olduğu bununla birlikte üniversite öğrencilerinin büyük bir kısmının kendi memleketinin dışında farklı bir kültürde yaşadığı bir dönemdir. Olumsuz duygulanımın, duygusal dengesizliğin, kaygı, stres, öfke ve pişmanlık gibi duyguları daha sık yaşayan üniversite öğrencilerinin yaşamlarının olumsuz etkilendiği ve yaşam doyumlarının da bu nedenle daha düşük olabileceği görülmüştür. 


\section{Yaşam Doyumunu Yordamayan Değişkenler}

Üniversite öğrencilerinin yaşam doyumlarının incelendiği bu araştırmada beş faktör kişilik kuramındaki kişilik özelliklerinin yaşam doyumunun anlamlı bir yordayıcısı olup olmadığı araştıılmış ve nevrotiklik kişilik özelliği dışındaki kişilik özelliklerinin yaşam doyumunun anlamlı birer yordayıcısı olmadıkları sonucuna ulaşılmıştır. Ulaşılan bu sonuç alanyazında ki birçok çalışmanın bulguları ile paralellik göstermektedir. Şimşek ve Aktaş (2016) örgütsel sessizlik, kişilik ve yaşam doyumu ilişkisi üzerine yaptıkları çalışmada nevrotiklik dişındaki diğer kişilik özelliklerinin yaşam doyumunun anlamlı bir yordayıcısı olmadığı bulgusuna ulaşmışlardır. Doğan (2013) kişilik özellikleriyle öznel iyi oluş arasındaki ilişkileri incelemiş, beş faktör kişilik kuramındaki deneyime açılık, uyumluluk ve sorumluluk kişilik özelliklerinin yaşam doyumunu istatistiksel olarak anlamlı bir şekilde yordamadığını tespit etmiştir. Diener ve Lucas (1999) yaptıkları araştırmada dışadönüklük ve nevrotiklik dışındaki diğer kişilik özelliklerinin yaşam doyumunu anlamlı bir şekilde yordamadığı neticesine ulaşmışlardır. Schimmack, Radhakrishnan, Oishi, Dzokoto ve Ahadi (2002) yatıkları çalışmada benzer bir sonucu elde etmiş dışadönüklük ve nevrotiklik haricindeki kişilik özelliklerinin yaşam doyumunu anlamlı bir şekilde açılamadığını tespit etmişlerdir. Heidemeier ve Göritz (2016) çalışmalarında yaşam doyumunun anlamlı yordayıcıları olarak nevrotiklik ve dışadönüklük kişilik özelliğini belirlerken kişiliğin diğer boyutlarının yaşam doyumunu yordamadığını sonucuna ulaşmışlardır. Eryılmaz ve Ercan (2011) ile İlhan ve Bacanlı (2007) da alanyazında ki birçok çalışma ile benzer şekilde nevrotiklik ve dışadönüklük dışındaki kişilik özelliklerinin öznel iyi oluşu anlamlı bir şekilde yordamadığını tespit etmişlerdir.

Alanyazında ki yaşam doyumu veya öznel iyi oluş ile beş faktör kişilik özellikleri arasındaki ilişkilerin incelendiği araştırmalarda nevrotiklik (duygusal dengesizlik) ve dişadönüklük değişkenlerinin üzerinde daha çok durulduğu ve yaşam doyumunun bu kavramlarla daha çok ilişkilendirildiği görülmektedir (Eryılmaz ve Ercan, 2011).

Alanyazında ki birçok çalışmada dışadönüklük ve nevrotiklik kişilik özelliklerinin yaşam doyumunun anlamlı bir yordayıcısı olduğu ancak diğer kişilik özelliklerinin (deneyime açıklık, uyumluluk, sorumluluk) ise ya etkisinin az olduğu ya da yaşam doyumunu anlamlı bir şekilde yordamadığı so- 
nucu elde edilmiştir. Bu araştırmada da ilgili alanyazın ile paralel olarak d1şadönüklük değişkeni tek başına analize dahil edildiğinde yaşam doyumunu anlamlı bir şekilde yordadığı görülmüştür. Ancak değişkenlerin yordama güçlerini belirleyebilmek için yapılan aşamalı (adımsal) regresyon analizinde dışadönüklük değişkeni yaşam doyumunu yordayan diğer değişkenler (yımazlık, bilinçli farkındalık, nevrotiklik) ile birlikte analize dahil edildiğinde perdelenmekte ve yordayıcılığı ortadan kalkmaktadır. Yılmazlık, bilinçli farkındalık ve nevrotiklik değişkenlerinin yaşam doyumunu güçlü bir şekilde yordaması dışadönüklük değişkenini geri plana düşürmektedir.

Dışadönüklüğün yaşam doyumunun anlamlı bir yordayıcısı olmamasında çalışma grubunun özellikleri de etkili olmuş olabilir. Beş faktör kişilik envanterinden elde edilen sonuçlara göre dişadönüklük puanlarının aritmetik ortalamasının diğer kişilik özelliklerine göre daha düşük olduğu görülmektedir. Çalışma grubunun dışadönüklük kişilik özelliğinin düşük olması yaşam doyumunu yordamasına engel olmuş olabilir. Özetle diğer değişkenlerin yordama güçlerinin yüksek olması, araştırmanın çalışma grubunun d1şadönüklük kişilik özelliğinin düşük olması dışadönüklüğün yaşam doyumunu anlamlı bir şekilde açıklamasını engelleyen sebepler olabilir.

Benzer şekilde deneyime açıklık, sorumluluk ve uyumluluk kişilik özelliklerinin diğer değişkenler ile birlikte yaşam doyumu üzerindeki etkisi incelendiğinde bu kişilik özelliklerinin araştırmadaki diğer değişkenlere göre etkisinin oldukça az olması yaşam doyumunu anlamlı bir şekilde yordamalarını engelliyor olabilir.

\section{Öneriler}

\section{Uygulamaya Yönelik Öneriler}

$\checkmark$ Üniversitede eğitim almakta olan öğrenciler yaşamlarının bu döneminde gerek maddi konularda gerekse sosyal ve akademik konularda çeşitli zorlayıcı durumlarla karşı karşıya kalmaktadırlar. Yaşamlarındaki bu zorlayıcı ve stresli durumlar bireylerin yaşamlarından aldıkları doyumu önemli ölçüde etkilemektedir. Araştırma sonuçları dikkate alındığında zorlayıcı yaşam durumları karşısında yılmazlık becerileri yüksek olan bireylerin yaşam doyumlarının da daha yüksek olacağı görülmüştür. Bu nedenle üniversite öğrencilerinde yılmazlığı geliştirici çalışmalar yapılması oldukça önemlidir. Bu amaç doğrultusunda Üniversitelerdeki Psikolojik Danışma 
ve Rehberlik Merkezlerinin yılmazlığı geliştirmek için grupla psikolojik danışma uygulamaları yapılabilir.

$\checkmark$ Araştırmada elde edilen sonuçlara göre farkındalık (mindfulness) düzeyi daha fazla olanların yaşamlarından daha çok doyum sağladıkları görülmüştür. Yaşamından doyum almayan başka bir ifadeyle düşük doyuma sahip öğrencilerin ne sosyal anlamda ne de akademik anlamda başarılı olması beklenemez. Yaşamının farkında olan geçmişin pişmanlıklarından geleceğin kaygısından uzak olan bireyler ise yaşamlarından daha çok doyum almaktadırlar. Hayatın bu döneminde çeşitli yaşam görevlerini yerine getirmeye çalışan bireyin yaşam doyumunu arttırmak için farkındalı̆̆ arttırıcı uygulamaların üniversitelerin Psikolojik Danışma ve Rehberlik Merkezleri tarafindan yapılması oldukça yerinde olacaktır. Bu kapsamda Gestalt Kuramı'nın farkındalığı arttırıc teknikleriyle birlikte grup rehberliği veya grupla psikolojik danışma çalışmaları da yapılabilir.

$\checkmark$ Araştırma sonucunda Beş Faktör kişilik özelliklerinden birisi olan Nevrotiklik(duygusal dengesizlik) kişilik özelliği yüksek olan bireylerin ise yaşam doyumlarının daha düşük olduğu sonucuna ulaşlmıştır. Duygusal anlamda tutarsızlık yaşayan bireylerin gerek akademik gerek sosyal anlamda daha da zor yaşantıları olduğu bunun da yaşam doyumu üzerinde olumsuz etkisinin olduğu düşünülmektedir.Bu nedenle duygusal tutarsızlık yaşayan ve bu konuda psikolojik desteğe ihtiyacı olan bireylere üniversite PDR birimleri tarafindan psikolojik danışma hizmeti sağlanması, öz güven eğitimleri verilmesi, duygularla çalışılması oldukça yerinde olacaktır.

$\checkmark$ Beş Faktör kişilik özelliklerinden birisi olan dışadönüklük kişilik özelliği daha baskın olan bireylerin yaşamlarından daha çok doyum aldıkları sonucuna ulaşılmıştır. Bu bilgiler ışığında sosyal anlamda kaygı yaşayan, daha içine kapanık ve sorumluluk üstlenmekten kaçınan öğrencilerin tespit edilerek gönüllülük ilkesi doğrultusunda üniversite PDR birimlerinin atılganlık çalışmaları yapması bu açıdan oldukça önemlidir. Bu kapsamda atılganlık içi grupla psikolojik danı̧ma veya psikoeğitsel gruplar yapılabilir.

\section{Yapılacak Olan Çalışmalar İçin Öneriler}

$\checkmark \quad$ Bu araştırma Gaziantep Üniversitesinde eğitim görmekte olan 554 lisans öğrencisiyle sınırlıdır. Bu nedenle daha farklı örneklem gruplarıyla benzer 
çalışmalar yapılması yaşam doyumunu açıklayan değişkenlerin etkilerinin anlaşılabilmesi bakımından oldukça faydalı olacaktır.

$\checkmark$ Bu çalışmada üniversite öğrencilerinin yaşam doyumlarının yordayıcıları olarak beş faktör kişilik özellikleri(Dışadönüklük, uyumluluk, sorumluluk, nevrotiklik, açıklık), Bilinçli farkındalık ve yılmazlık değişkenleri ele alınmıştır. Sınırlı sayıdaki bu değişken grubundan farklı olarak yaşam doyumu üzerinde etkisi olduğu düşünülen diğer değişkenler(psikolojik dayanıklılık, mükemmeliyetçilik, dini inanç, yalnızlık, tükenmişlik, özsaygı, iyimserlik, stresle başa çıkma, benlik saygısı, internet bağımlılı̆̆ı, sosyal medya kullanımı vb.) gelecek çalışmalarda araştırmacılar tarafından kullanulabilir.

$\checkmark$ Üniversite öğrencilerinin yaşam doyumlarının daha detaylı incelenebilmesi için daha farklı ve kapsamlı modeller kullanılabilir. Bu araştırmada yordayıcı değişkenlerin birbirleriyle de ilişkisi olduğu sonucuna ulaşılmıştır. Bundan ötürü alan yazın da dikkate alınarak gelecek çalışmalarda yapısal eşitlik modeli kullanılması yaşam doyumunun daha detaylı bir şekilde incelenmesine olanak sağlayabilir.

$\checkmark$ Bu çalışmada beş faktör kişilik özelliklerinin ölçülebilmesi için “Beş Faktör Kişilik Envanteri" kullanılmıştır. Bacanlı ve ark. (2009) tarafından geliştirilen "Sıfatlara Dayalı Kişilik Testi" beş faktör kişilik kuramına dayalı olarak geliştirilen 40 maddelik bir ölçektir. Gelecek çalışmalarda kişilik özelliklerini ölçmek amacıyla bu ölçeğin kullanılarak yaşam doyumunun incelenmesi ve beş faktör kişilik envanteriyle çalışılan araştırmalarla karşılaştırılarak tutarlı sonuçların çıkıp çıkmadığının araştırılması da öneri olarak sunulabilir.

Bu çalışmada yılmazlık ve bilinçli farkındalık değişkenlerinin yaşam doyumunu anlamlı bir şekilde yordadığı belirlenmiştir. Bu sonuca göre gelecek çalışmalar için deneysel bir araştırma planlanabilir. Ön Test-Son Test Kontrol gruplu bir deneysel çalışmada yaşam doyumu, yılmazlık ve bilinçli farkındalık düzeyleri ölçülerek yılmazlık ve farkındalığı geliştirici çalışmalar için grupla psikolojik danışma programı uygulanabilir. Sonrasında tekrar yaşam doyumları ölçülerek ön test ile son test arasında anlamlı bir farklılaşmanın olup olmadığı kontrol edilebilir. Böylece hem grup oturumlarının etkililiği hem de yılmazlık ve bilinçli farkındalığın yaşam doyumu üzerindeki etkisi gözlenebilir. Kontrol grubu ise bize zamanın etkisinden bağımsız olarak yaşam doyumunun artıp artmadığını gösterecektir. 


\title{
EXTENDED ABSTRACT
}

\section{Life Statisfaction Of University Students: The Five Factor Personality Traits, Mindfulness And The Role Of Resilience}

\author{
Aytekin Nam, Sinem Evin Akbay \\ Mersin Üniversitesi-Aktoprak İlkokulu
}

One of the important issues that has been discussed for many years is how a good life should be. In this process, various thoughts have been put forward, such as that a good life is about being virtuous, that the individual should fulfill his / her duties and responsibilities correctly, or that it should be full of joy (Diener and Suh, 2000). One of the most important life goals for people is to lead a happy life. The questions of how to maintain a happy life, how can people be happy, what factors are affected by happiness, what does happiness mean have never gone out of date (Çivitçi, 2012).

While the word "satisfaction" in the concept of Life Satisfaction is explained as meeting the expectations, desires and needs of the individuals, the term "Life Satisfaction" is the result that the individual reaches after making a general evaluation by comparing his expectations with what he has (Şahin, 2008). The closer the current life of the individual to the ideal life, the higher the satisfaction he receives from his life. If we formulate this situation, we can say life satisfaction = dreams-lives. Here, life satisfaction decreases as the difference increases, life satisfaction increases as the difference decreases. The difference being close to zero indicates high life satisfaction. In summary, life satisfaction is the result of a person's subjective evaluation of his own life.

Personality is the innate nature of individuals and the unique temperament that distinguishes them from other people and the totality of their characteristics that appear in different situations (İbrahimoğlu, Ünaldı, Samancioğlu, and Connectedbel, 2013). The Five Factor Personality Model was first developed in 1985 by Paul Costa and Robert Mcrae (Merdan, 
2013) and later continued by various researchers with different personality traits from different nations. As a result of these researches, it was found that personality has five dimensions. Because of these five factors emerging in almost all of the studies, this theory has been called the "five factor personality theory" or in other words, the "big five". In short, these factors; extroversion is defined as openness to experience, self-discipline (Responsibility), adaptability and neuroticism (Burger, 2006).

Conscious awareness is a concept that expresses being in the moment, being free from past experiences and concerns of the future. Increasing the level of awareness of individuals is a factor that enables them to cope with pain effectively, to provide more satisfaction from their social relationships, and to increase mental health (Brown, Ryan, and Creswell, 2007).

The ability of an individual to overcome today's stressful and challenging living conditions is again dependent on the person's mental and social abilities and adaptation skills. The challenging situations faced by the person in his life, stressful events, and the positive characteristics he possesses despite all the negative conditions help the individual to minimize the negative effects of the environment (Onat, 2010). Resilience can also be expressed as the resilient stance individuals exhibit in the face of difficult and stressful life events. Student life is a period of life that includes many stressful events and difficulties. It is a curious situation how the life satisfaction of individuals with higher resilience will be affected by these difficulties and troubles

The aim of this study is to examine to what extent the personality traits, conscious awareness and resilience levels of university students in the five-factor personality theory predict their life satisfaction. The working group of the research consists of 351 female and 203 male undergraduate students in total, who are studying in various faculties and colleges of Gaziantep University in the 2018-2019 academic year. Relational scanning model, one of the general scanning models, was used as the research model. In the study, a total of 5 scales were used, including the Personal Information Form prepared by the researcher, as well as the Life Satisfaction Scale, the Five Factor Personality Scale, the Conscious Awareness Scale and the Resilience Scale. The data obtained as a result of the research were analyzed using the SPSS package program. Pearson correlation coefficient to examine the relationship between Life Satisfaction and Five- 
Factor Personality Trait, Conscious Awareness and Resilience levels; Multiple regression analysis was used to examine the role of five factor personality trait, conscious awareness and resilience levels in predicting students' life satisfaction. In order to determine the predictive power of these variables, stepwise regression analysis was used.

According to the results obtained from the study, it was concluded that neuroticism personality trait, conscious awareness and resilience variables were significant predictors of life satisfaction. With these findings, it was concluded that the variables of five-factor personality traits, conscious awareness and resilience together explained the life satisfaction scores of university students with a rate of $24.4 \%$. According to the stepwise regression analysis result, the predictive powers of the independent variables in the study are as follows: Resilience variable is the strongest variable that predicts the life satisfaction scores of university students and alone explains $19 \%$ of the total variance. Resilience and Conscious Awareness variables together explain $21.6 \%$ of the total variance. Resilience, Conscious Awareness and Neuroticism variables together predict 22.6\% of life satisfaction scores. These results are discussed and some suggestions for future studies are presented.

In this study, five factor personality traits (extroversion, adaptability, responsibility, neuroticism, openness), conscious awareness and resilience variables were considered as predictors of life satisfaction of university students. Unlike this limited number of variables, other variables that are thought to have an effect on life satisfaction (psychological resilience, perfectionism, religious belief, loneliness, burnout, self-esteem, optimism, coping with stress, self-esteem, internet addiction, social media use, etc.) will come. It can be used by researchers in studies.

\section{Kaynakça / References}

Albuquerque, I., Lima, M.P., Matos, M. ve Figueiredo, C. (2012). Personality and subjective well-being: What hides behind global analyses? Social Indicators Research, $105,447-460$

Alibekiroğlu, P., Akbaş, T., Bulut Ateş, F. ve Kırdök, O . (2018). Üniversite öğrencilerinde yaşam doyumu ile psikolojik sağlamlık arasındaki ilişkide öz anlayışın araci etkisi. Çukurova Üniversitesi Sosyal Bilimler Enstitüsü Dergisi, 27 (2) , 1-17 
Bacanlı, H., İhan T. ve Aslan, S. (2009). Beş faktör kuramına dayalı bir kişilik ölçeğinin geliştirilmesi: Sıfatlara dayalı kişilik testi (SDKT). Türk Eğitim Bilimleri Dergisi, 7(2), 261-279.

Batan, S.N. ve Ayten, A. (2016) Dinî başa çıkma, psikolojik dayanıklılık ve yaşam doyumu ilişkisi üzerine bir araştırma. Din Bilimleri Akademik Araştırma Dergisi, 15, 67-92.

Baysal, N. ve Dağlı, A. (2016). Yaşam doyumu ölçeğinin Türkçeye uyarlanması: geçerlik ve güvenirlik çalışması. Elektronik Sosyal Bilimler Dergisi, 59,. 1250-1262.

Brown, K. W. ve Kasser, T. (2005) Are psychological and ecological well-being compatible? The role of values, mindfulness, and lifestyle. Social Indicators Research.74, 349-368

Brown, K. W., Ryan, R. M., ve Creswell, J. D. (2007). Mindfulness: theoretical foundations and evidence for its salutary effects. Psychological Inquiry, 18(4), 211-237.

Brown, K.W. ve Ryan,R.M.(2003).The benefits of being present: Mindfulness and its role in psychological well-being. Journal of Personality and Social Psychology, 84, 822-848.

Burger, Jerry M. (2006). Kişilik: psikoloji biliminin insan doğasına dair söyledikleri. Çev. İ. Deniz, Erguvan Sarıoğlu, İstanbul, Kaktüs Yayınları, 251-252

Cengiz, R., Serdar, E., Donuk, B. (2016). Üniversite öğrencilerinin bilinçli farkındalık ve girişimcilik düzeylerinin incelenmesi. International Journal of Social Sciences and Education Research, 2(4), 1632-1643.

Ciccarelli, S. K. ve White, J. N. (2016). Psikoloji: birkeşifgezintisi. (D. N. Şahin çev.), Ankara: Nobel Akademik Yayıncilı.

Çelik, M., Sanberk, İ. ve Deveci E. (2017). Öğretmen adaylarının yaşam doyumlarının yordayıcısı olarak psikolojik dayanıklılık ve umutsuzluk. İköğretim Online, 16(2), 654-662

Çivitçi, A.(2012). Üniversite öğrencilerinde genel yaşam doyumu ve psikolojik ihtiyaçlar arasındaki ilişkiler. Çukurova Üniversitesi Sosyal Bilimler Ensitüsü Dergisi, 21(2), 321-336

Çivitçi, N. ve Arıcıoğlu, A. (2012). Beş faktör kuramına dayalı kişilik özellikleri. Mehmet Akif Ersoy Üniversitesi Ĕ̆itim Fakültesi Dergisi, 23, 78-96.

Deniz, M. E., Erus, S. M., ve Büyükcebeci, A. (2017). Bilinçli farkındalık ile psikolojik iyi oluş ilişkisinde duygusal zekânın aracilık rolü. Türk Psikolojik Danışma ve Rehberlik Dergisi, 7(47), 17-31

Demirel, S. ve Canat, S. (2004). Ankara'daki Beş eğitim kurumunda kendini yaralama davranışı üzerine bir çalışma. Kriz Dergisi, 12(3), 1-9. 
Diener, E. (2000). Subjective well-being: The science of happiness and a proposal for a national index. American Psychologist, 55 (1), 34-43.

Diener E. ve Suh E. M. (2000). Measuring Subjective Well-Bing to Copmare the Quality of Life of Culteres. In E. Diener ve E. M. Suh (Eds), Culture and Subjective WellBeing (p. 3-12). The Mit Press

Doğan, T. (2013). Beş faktör kişilik özellikleri ve öznel iyi oluş, Doğuş Üniversitesi Dergisi, 14(1), 56-64

Dönmez Ş. (2018). Çevrimiçi oyun bağımlhl̆ğını bilinçli farkındalık ve yaşam doyumu ile ilişkisi. Yüksek Lisans Tezi. Fatih Sultan Mehmet Vakıf Üniversitesi, İstanbul.

Durmuş, E., Ulusoy, Y. (2011). Kişilerarası bağımlılık eğiliminin beş faktör kişilik özellikleri açısından incelenmesi. İnönü Üniversitesi Eğitim Fakültesi Dergisi, 12(2), 01-21.

Ercan, H. (2019). Ergenlerde yaşam doyumunun demografik değişkenler, ebeveyn tutumları ve kişilik özellikleri açısından incelenmesi. Bolu Abant İzzet Baysal Üniversitesi Ĕ̆itim Fakültesi Dergisi, 19 (2), 501-516.

Erkuş, A. ve Tabak, A . (2010). Beş faktör kişilik özelliklerinin çalışanların çatışma yönetim tarzlarına etkisi: savunma sanayiinde bir araştırma. Atatürk Üniversitesi İktisadi ve İdari Bilimler Dergisi, 23 (2) , 213-242.

Eryllmaz, A. ve Ercan, L. (2011). Investigating of the subjective well-being based on gender, age and personality traits. Türk Psikolojik Danısma ve Rehberlik Dergisi, 4(36), 139-149

Eryılmaz, A. ve Öğülmüş, S. (2010). Ergenlikte öznel iyi oluş ve beş faktörlü kişilik modeli. Ahi Evran Üniversitesi Eğitim Fakültesi Dergisi, 3, 189-203

Furnham, A. ve Petrides, K. V. (2003). Trait emotional intelligence and happiness. Social Behavior and Personality, 31(8), 815-824.

Gürgan, U. (2006). Grupla psikolojik danışmanın üniversite öğrencilerinin yılmazlık düzeylerine etkisi (Doktora Tezi) Ankara Üniversitesi, Ankara.

Gürgan, U. (2014). Üniversite öğrencilerinin yılmazlık ve iyilik halinin bazı değişkenlere göre incelenmesi. NWSA-Education Sciences, 9(1), 18-35

Griebel, C. (2015). Emotional mtelligence as a mediator in the relationship between mindfulness and subjective well-being. Yayımlanmamış doktora tezi. Eastern Illinois University, Illinois

Heady, B. ve Wearing, A. (1989). Personality, life events, and subjective well being: towards a dynamic equilibrium model. Journal of Personality and Social Psycho$\log y, 57,731-739$.

Heidemeier, H. ve Göritz, A. S. (2016). The Instrumental role of personality traits: using mixture structural equation modeling to investigate individual differences in the relationships between the big five traits and life satisfaction. Journal of Happiness Studies 17(6), 2595-2612. 
Howell, A. J., Digdon, N. L., Buro, K. ve Sheptycki, A. R. (2008). Relations among mindfulness, well-being, and sleep. Personality and Individual Differences, 45, 773-777.

İbrahimoğlu, N., Ünaldı, İ., Samancioğlu, M. ve Bağlıbel, M. (2013). The relationship between personality traits and learning styles: a cluster analysis, Asian Journal of Management Sciences and Education, 2(3), 93- 108.

İthan, T. ve Bacanl, H. (2007). Mizah tarzları, kişilik özellikleri ve öznel iyi oluş: Bir model denemesi. Eğitim Bilimleri ve Uygulama Dergisi, 11, 35-52

İnanç, B. Y. ve Yerlikaya, E. E. (2017). Kişilik kuramları. 13. Baskı Ankara: Pegem Akademi Yayınları

Karabulut, Ö. Ö. ve Özer, M. (2003). Yaşlılarda yaşam doyumu. Geriatri, 6(2), $72-.74$

Limonero, J. T., Tomás Sábado, J., Fernández Castro, J., Gómez Romero, M. J., ve Ardilla Herrero, A. (2012). Resilient coping strategies and emotion regulation: predictors of life satisfaction. Psicol Conduct, 20(1), 183-196.

Merdan, E. (2013). Beş faktör kuramı ile iş değerleri ilişkisinin incelenmesi: Bankacllı sektöründe bir araştırma. Gümüşhane Üniversitesi Sosyal Bilimler Elektronik Dergisi, 4(7), 140-159

Moran C. ve Hughes L (2006) Coping with stress: Social work students and humour, Social Work Education. 25(5), 501-517.

Morrison, K. A. (1997). Personality correlates of the five-factor model for a sample of business owners/managers: associations with scores on self-monitoring, type a behavior, locus of control, and subjective well-being. Psychological Reports, 80, $255-272$

Morsünbül, Ü. (2014). Hızlı büyük beşli kişilik testi Türkçe versiyonu geçerlilik ve güvenirlik çalışması. Düşünen Adam: The Journal of Psychiatry and Neurological Sciences, 27, 316-322.

Onat, G. (2010). Demokratik ve otoriter olarak alglanan ana-baba tutumlarmm lise birinci smif öğrencilerinin yllmazlk düzeyine etkilerinin araştırlması. Yüksek Lisans Tezi). Maltepe Üniversitesi, İstanbul.

Obuz, B. (2019). Bel ağrnsı olan hastalarda beş faktör kişilik özelliklerinin bedensel duyumlarn abartma ve somatizasyon ile ilişkisinin incelenmesi. Yüksek Lisans Tezi). Beykent Üniversitesi, İstanbul.

Orhan, S. (2018). Üniversite öğrencilerinin dizi karakterleri ile kurdukları parasosyal ilişkideki ikietken:psikolojik sağlamlikve yaşam doyumu. Yüksek Lisans Tezi. Kırıkkale Üniversitesi, Kurkkale.

Özdaş, İ. (2017). Yetişkinlerde ait olma ihtiyacı, psikolojik dayanıklllk ve yaşam doyumu arasındaki ilişkinin incelenmesi. Yüksek Lisans Tezi. Beykent Üniversitesi, İstanbul. 
Özgür, G. Gümüş, A, ve Durdu, B. (2010). Evde ve yurtta kalan üniversite öğrencilerinde yaşam doyumu, Psikiyatri Hemşireliği Dergisi, 1(1), 25-32

Penley, J. A. ve Tomaka, J. (2002). Associations among the big-five, emotional responses, and coping with acute stress. Personality and Individual Differences, 32, 1215-1228.

Reisoğlu, S. (2014). Üniversite öğrencilerinin öznel iyi oluşlarm yordamada beş faktör kişilik özellikleri, mizah tarzları ve duygusal zekânın rolü. Doktora Tezi. Karadeniz Teknik Üniversitesi, Trabzon.

Reisoğlu, S., ve Yazıcı, H. (2017). Üniversite öğrencilerinin öznel iyi oluşlarını yordamada beş faktör kişilik özellikleri, mizah tarzları ve duygusal zekânın rolü. Journal of History Culture and Art Research, 6(4), 888-912.

Sarıçalı, M. ve Satıc, S. A. (2017). Bilinçli farkındalık ile psikolojik kırılganlık ilişkisinde utangaçlığın arac rolü. Hitit Üniversitesi Sosyal Bilimler Enstitüsü Dergisi, 1, 655670

Schimmack,U., Radhakrishnan, P., Oishi, S., Dzokoto, V. ve Ahadi, S. (2002). Culture, personality, and subjective well-being: Integrating process models of life satisfaction. Journal of Personality and Social Psychology, 82, 1313-1329.

Schutte, N. S. ve Malouff, J. M. (2011). Emotional intelligence mediates the relationship between mindfulness and subjective well-being. Personality and Individual Differences, 50(7), 1116-1119.

Somer, O., Korkmaz, M., ve Tatar, A. (2002). Beş Faktör Kişilik Envanteri'nin geliştirilmesiI: ölçek ve alt ölçeklerin oluşturulması. Türk Psikoloji Dergisi,17 (49), 21-33.

Sümer, N. , Sümer, H.C. (2005). Beş faktör kişiliközellikleri ölçeği.Yayınlanmamış çalışma Şahin, A. (2019). Üniversite öğrencilerinde bilinçli farkındalık ile yaşam doyumu ve iyi oluş arasındaki ilişkiler. Üsküdar Üniversitesi Sosyal Bilimler Dergisi, 8, 151-176.

Şahin, Ş. (2008). Beden eğitimi öğretmenlerinin tükenmişlik ve yaşam doyum düzeyleri. Yayımlanmamış Doktora Tezi, Mersin Üniversitesi, Sağlık Bilimleri Enstitüsü, Mersin.

Şimşek, D. ve Aktaş, Y. (2016). Örguitsel sessizlik ile kişilik ve yaşam doyumu etkileşimi: Kamu sektöründe bir araştırma. Anadolu Üniversitesi Sosyal Bilimler Dergisi, 14(2) , 121-136.

Tuncer, N. (2017). Bir grup üniversite öğrencisinde belirlenen sosyal anksiyete düzeylerine göre bilinçli farkındalık ve yaşam doyumu düzeylerinin incelenmesi.Yüksek Lisans Tezi. Işı Üniversitesi, İstanbul.

Tümkaya, S., Hamarta, E., Deniz, M. E., Çelik, M., ve Aybek, B. (2008). Duygusal zeka mizah tarzı ve yaşam doyumu: Üniversite öğretim elemanları üzerine bir araştırma. Türk Psikolojik Danışma ve Rehberlik Dergisi, 3(30), 1-18. 
Tümlü, G. Ü., Recepoğlu, E. (2013). Üniversite akademik personelinin psikolojik dayanıklılık ve yaşam doyumu arasındaki ilişki. Yükseköğretim ve Bilim Dergisi, 3(3),205-213

Uzunoğlu, S. (2006). Kişiliğin deşifresi. İstanbul: Morpa Kültür Yayınları.

Uz Baş, D ve Yurdabakan, D. (2017). Psikolojik sağlamlık ve okul ikliminin ortaokul öğrencilerinin yaşam doyumunu yordama gücü. Mehmet Akif Ersoy Üniversitesi Eğitim Fakültesi Dergisi, 1 (41) , 202-214

Wang, Y. ve Kong, F. (2014). The role of emotional intelligence in the impact of mindfulness on life satisfaction and mental distress. Social Indicators Research, 116(3), 843-852

Weber, M. ve Huebner, E.S. (2015). Early adolescents' personality and life satisfaction: A closer look at global vs. domain-specific satisfaction. Personality and Individual Differences, 83, 31-36.

Yıkılmaz, M. ve Güdül, M. D. (2015). Üniversite öğrencilerinde yaşam doyumu, yaşamda anlam ve bilinçli farkındalık arasındaki ilişkiler. Ege Eğitim Dergisi, $16(2), 297-315$.

Zümbül, S. (2019). Öğretmen adaylarının psikolojik iyi oluş düzeylerindebilinçli farkındalık ve affetmenin yordayıc rolleri. Ege Ĕ̈itim Dergisi, 20 (1) , 20-36

Tavşancil, E. (2010). Tutumlarm ölçülmesi ve SPSS ile veri analizi. Ankara: Nobel Yayın Dağıtım.

Tezbaşaran, A. A. (1997). Likert tipi ölçek geliştirme kllavuzu. Ankara: Türk Psikologlar Derneği.

Trompenaars, F. ve Voerman, E. (2009). Servant-leadership across cultures: Harnessing the strengths of the world's most powerful management philosophy. New York: The McGraw-Hill Companies.

Vinod, S. ve Sudhakar, B. (2011). Servant leadership: A unique art of leadership, Interdisciplinary Journal of Contemporary Research in Business, 2(11), 456-467.

Yılmaz, V. ve Çelik, H. E. (2009). Lisrel ile Yapısal Eşitlik Modellemesi I Temel Kavramlar, Uygulamalar, Programlama. Ankara: Pegem Akademi Yayıncllk.

\section{Kaynakça Bilgisi / Citation Information}

Nam, A. ve Akbay,S.E. (2020). Üniversite öğrencilerinde yaşam doyumu: Beş Faktör kişilik özellikleri, bilinçli farkındalık ve yılmazlığın rolü. OPUS-Uluslararası Toplum Araştırmaları Dergisi, 16(31), 42104237. DOI: 10.26466/opus. 719138 